\author{
Viktor Trajanovski (North Macedonia) \\ Institute of Ethnology and Anthropology \\ Faculty of Natural Sciences and Mathematics \\ Ss. Cyril \& Methodius - Skopje \\ E-mail: trajanovskiv@yahoo.com
}

\title{
THE BEKTASHI ORDER OF DERVISHES IN MACEDONIA DURING SOCIALISM
}

\begin{abstract}
The proposed paper aims to offer the reader certain data on the most significant features and specifics of the Bektashi dervish order in Macedonia during the socialist period. Certain political decisions are included, as well as social occurrence and processes that will directly affect on the (non)existence of certain Bektashi tekkes (lodge), but also on the course of bektashi life in general.
\end{abstract}

Key words: The Bektashi order of dervishes, doctrine, socialist period, "free emigration agreement", "five-year plan“, „nationalization“.

Socialism as an ideology and as a basis for the social organization of a number of countries around the world is constantly in the interest of the researchers, especially after its decline and the changes that took place in the early 1990s. Many researchers who have chosen to study socialism have focused their attention on analyzing certain religious issues. This paper is just one of many which elaborate certain religious issues during socialism, i.e. the aim of the paper is to offer to the readers as detailed information as possible about the most important characteristics and specifics of the Bektashi dervish order in Macedonia during the socialist period.

At the very beginning of this paper I would like to briefly introduce the reader to the basic postulates of the Bektashi tariqa, i.e. the Bektashi dervish order as many like to call it, in order for the reader to have a clearer picture of this tariqa.

The Bektashi dervish order belongs to the esoteric side of Islam, known as sufism or tasawwuf, whose basic goal is the inner ascension and realization of the oneness of God, that is, a way of life aimed at uniting with the Absolute Truth, i.e. with God. 
One of the main predispositions that should be possessed by the individual who has decided to follow the path of sufism is the affiliation to Islam, because the methods of sufism are ineffective without this religious affiliation. (See: Што е тоа Суфизам: http://www.islamska-zaednica.com/forum/topic/945-што-етоа-суфизам/).

The Bektashi dervish order is associated with the name of Haji Bektash Veli, who is considered the founder and spiritual leader of this order, according to whom this tariqa bears his name. Haji Bektash Veli originated from the town of Nishabur in the Persian province of Khorasan, in present-day Iran, a place considered the cradle of Sufism. He came to Asia Minor in the 13th century, settled in the neighborhood of Kirşehir, in the village of Suluca Karahoyuk (turkish: Suluca Karahöyük) which later took its name Haji Bektash (Birge, 1937: 50). There he established the Sufi center, the main Bektashi shrine, known as Pir Evi, from where missionaries were later sent to spread the Bektashi tariqa throughout Anatolia and the Balkans..

The Bektashi tariqa, in the form we know it today, wasn't profiled until the 16th century. The individual responsible for determining the structure of the Bektashi order was Balım Sultan (1473-1516). He carried out a large number of reforms, had control over everything and unified Bektashi rules. As a result of this transformation Balım Sultan is considered as the second saint and the second founder (tur. İkinci Pir, per. Piri Sani). (Birge, 1937: 56).

As far as the essence of the Bektashi teaching goes, the dogmas or most important points of the religious studies, the Bektashi tariqa offers a unique and familiar reading of the Quran; adherence to the rules and practices of the prophet Muhammad and hasreti (saint) Ali; respect towards the family of the messenger Muhammad, the "Ehl-i Beyt"; respect towards the 12 imams and 14 innocent victims, so called Masumi (Mâsûm-u Pâk); also, the belief in wālis or saints; following the holy path of Hunkar Haji Bektash Veli and the doctrine of the four gates which cannot be imagined without the face of the murshid or teacher who understands best the road to Allah, or the Haq (Truth). (See: Ćehajić, 1986: 162; The Path to Insight: http://bektashiorder.com/the-path-to-insight).

What separates Bektashis from conventional Islam is non-compliance with certain Sharia rules. So, the Bektashis do not fast during the month of Ramadan, they do not perform the five-day prayer or namaz, then they use dem or alcohol during their rituals, but in their daily life, they did not consider pilgrimage a mandatory rule, so they will often say: our pilgrimage is not to go and worship in Mecca, but to enter in the heart of our murshids.

For Bektashi most important religious holidays are Sultan Nevruz and Ashure. These two major events that are interwoven with diverse beliefs, customs and magical activities occupy an important place in the life of the Bektashi community in the Republic of Macedonia.

The cause for celebrating Nevruz, or as some have called it Sultan Nevruz is the birthday of Imam Ali, which is celebrated on the 21st of March, which coincides with the date of the commencement of spring. 
The second significant event for the Bektashi religious celebration is the day of Ashure. It is a mourning holiday, to commemorate the death and martyrdom of Imam Hussein, the son of Imam Ali and grandson of the Prophet Muhammad, who was killed in the town of Karbala, present day Iraq, by supporters of the Umayyad caliph Yazid. (See: Конеска, 2008: 423; Јордановска 2014).

For Bektashis the holy temple is tekke or lodge. It is a place where they perform their religious rites and ceremonies. Tekke is a prayer house, a place for contemplation and search for the Reality. (Kara, 1999: 50 cited in: Изети 2008).

Guided by the doctrine of equality of all human beings before God, the Bektashi order of dervishes is the only one that integrates women by giving them equal treatment with men, as participants in spiritual rituals, but also as partners in everyday life.

Although Islam in Macedonia spread, mainly, as Sunni, along with it came different teachings, movements and institutions, i.e. myriads of dervish orders known also as tariqas, with different ideologically-religious orientations, from the conservative to the revolutionary. (Стојановски, 1998: 393).

The mosaic made up of dervish orders which existed in Macedonia is very colourful. For its colourfulness most deserving are these tariqas: Kadiri, Rifai, Shazeli, Halveti, Sadi, Nakshibendi, Bajrami, Melami, Bektashi, etc.

Judging by the tekkes (lodges) and türbes (mausoleums) that can be found throughout the territory of Macedonia, it can be said that the Bektashi dervish order was one of the most widely spread tariqas in Macedonia.

The presence of the Bektashi tariqa in Macedonia in the 16th century is testified by the oldest written document, connected with a certain Bektashi sanctuary. It is a record from 1544, whose original is kept in the "Archive of the presidency of the government of the Republic of Turkey" in Istanbul. It tells about the tekke Hıdır-Baba (Петровски 1994: 84; Стојановски 1979: 55) in Makedonski Brod which is thought to be the oldest Bektashi sanctuary in Macedonia. (Види: Hasluck F. W. 1929: 523-525).

It is assumed that the Dikmen-Baba tekke in Kanatlarci, and the HarabatiBaba tekke (also known as Sersem Ali-Baba tekke) in Tetovo originate from the same period, the 16th century.

In the past on the territory of Macedonia there were several Bektashi tekkes. So, there were Bektashi tekkes in the following places: Bitola, the HusainBaba's tekke; in Kičevo H'd'r-Baba; in Skopje Mustafa-Baba and Suleyman-Baba; near the station of Aleksandrovo, between Kumanovo and Skopje, little tekke with the tomb of Karadzha Ahmed; in Strumica, i.e. in the Strumica area, Ismail Baba (Izeti 2001: 163), tekkes Jarar-Baba and Kojun-Baba in Tetovo area, JaferBaba tekke in Gostivar (Изети, 2008: 196), Hamza-Baba in Štip, Haje-Baba in Veles, Ali-baba in Debar. Then, in the village of Karatmanovo was the shrine of Kamber Baba, in the village of Džumali, Yusuf Dede, the village of Tatarli Ilmi Dede and others. 
When we talk about the Bektashi tariqa in socialist period, it is impossible to surgically remove it precisely and to perceive it as a separate entity exclusively in Macedonia. Certain processes and occurrences that took place within Yugoslavia, had equal importance and application at the level of all Republics, i.e certain laws and decisions that were adopted had equal application among all residents of SFR Yugoslavia. Also, certain Bektashi elders had full legitimacy to manage several tekkes spread throughout SFR Yugoslavia.

In the period from 1945 to 1990, the Bektashi tekke in Gjakova stood out in the former Yugoslavia under the leadership of Qazim Bakali-Baba, who became an elder of the entire Balkan region, in Macedonia, Kosovo, Albania. This tekke played an important role in preserving the Bektashi tradition in this area (Ćehajić, 1986: 172; Конеска, 2009: 234), so that we can rightly call it the Bektashi pearl during socialism in the Balkans. Many dervishes from different tekkes, especially in Macedonia, were appointed to the leadership position of babas by this tekke, i.e. by the head of this tekke, the highly respected elder Qazim Bakali.

Qazim Bakali... He was the leader in SFR Yugoslavia ... for the Bektashis 1.

... It was considered as a center for the Bektashis... Đakovo, Đakovica in Kosovo. Also, it was until some time ago the center of the world Bektashis. Until Albania was not an open country ${ }^{2}$.

Despite this positive activity performed by this tekke in Gjakova and Qazim Bakali-Baba, there is another significant event to be underlined in this (socialist) period, that is the "Free Emigration Agreement", concluded between the FNR Yugoslavia and the Republic of Turkey in the 1950s, also known as the "Gentlemen's Agreement", which envisages the emigration of the Turkish population from the Federal Republic of Yugoslavia to the Republic of Turkey. This agreement was dire to the tariqa life and tekkes in Macedonia. The tariqas in Macedonia were most exposed to the emigration of the Muslim population to Turkey. By the 1960s, many tekkes in the area of the Socialist Republic of Macedonia, once inhabited by Turks, were devastated as a result of population displacement.

And after that, our people changed their minds and returned to Turkey, when the SFRY had already arrived. The Ottomans lost here, they ended up. Five hundred and sixty years as long as they kept Macedonia here. Already when they lost, then royal Yugoslavia came, then came I do not know Serbian Yugoslavia, what kind of Yugoslavia it was, so Tito brought us SFRY, Socialist Federal Republic of Yugoslavia. And an agreement is being made, whoever wants can go to Turkey. So to return to their homeland... No, it was arbitrary, there was no pressure, but they were afraid ${ }^{3}$...

1 Own field research, 2013, southern part of Macedonia, dervish in the Bektashi tariqat at the age of 50 , Turk.

2 Own field research in Ohrid, 2018. Interlocutor Eyup Salih, born on September 22, 1950 in Ohrid, muslim, Turk.

3 Own field research, 2019, southern part of Macedonia, dervish in the Bektashi tariqat at the age of 60 , Turk. 
One glaring example that reflects this situation is the one from the village of Gorno Vranovci, Veles region. During this period, there is a mass emigration of Vranovci residents to Turkey. The whole village, with the exception of one family, is moving to Turkey, which will be fatal for the Bektashi life in Gorno Vranovci.

Aneta Svetieva during her field research in this village made in 1999, within the project "Multicultural and ethnic facilities of four villages in Veles region", came across several graves whose monuments, according to her, had Bektashi features, and then, her conclusion to be confirmed by her interlocutor, the only native who opposed the phenomenon called migration and remained living in Gorno Vranovci. The data obtained from her research would later be presented in her paper entitled "The villages of Melnica and Gorno Vranovci in Veles" where the author says: "It seems Sunni Islam did not have deeper roots, which is evidenced by the remains of the four dervish tombs that people call "tekkes", then the symbols on the tombstones, and until recently there were remains of the so-called "dervish mosque". According to the information from the field, there were members of the dervish orders "Bektashi" and "Rifai" in the village. The mass emigration of Vranovci locals to Turkey began around the 1950s. Today there is only one indigenous family in the village. Today's inhabitants are mainly Albanians from Kosovo and the neighboring Albanian villages of Gorno and Dolno Jabolčišta in Veles region, who immigrated in parallel with the emigration of the people from Gorno Vranovci. (Светиева: http://www.ethnologs-dep.org/ VELES/indexV.htm).

After receiving the data from Aneta Svetieva, but also the text she wrote, I tried to find out certain data about the former Bektashis from this settlement, through my acquaintances with people who are descendants of emigrants from Vranovci in Turkey. After several unsuccessful attempts and contacts, in the end I came across Muharrem Aksu who confirmed such findings of Aneta Svetieva, but this time with specific names of some of the families, but also of the awlies, i.e. the saints.

Muharem Aksu (old family name Osmanoski) was born in 1945 in Gorno Vranovci and lived there for ten years, i.e. until 1955, before his family moved to Izmir, Republic of Turkey.

Osmanoski, during the Turkish period Osman, than Osmanovci. From my mother, maiden name Fazloska. My grandfather was in 1944 with my uncle, they were beaten to death by the Bulgarian Chetniks. When we left for Turkey, we changed our family names. Most of our surnames are from the place near Vranovci, for example: Bela Voda - Aksu, Dalga (long) Livada - Uzunbair, Crn Kamen - Karatash and so on ${ }^{4}$.

Regarding the Bektashis and the Bektashi tariqa in his birthplace or memleket, Muharrem shared the following with me: Yes, they were Bektashis in Vranovci. There were Bektashi dervishes and Rufai and there were Melamis. There were families called Suruđijovci, they were Bektashis. We have Ramadan-

4 Own field research. Interlocutor Muharem Aksu (Osmanoski), born in 1945 in Gorno Vranovci. Today he lives in Izmir, Republic of Turkey. 
Baba in Vranovci, he was a Bektashi-Baba saint. His grave is upstairs in sheltered spot. They have Bektešovci in Vranovci, now they are Bektashlar ${ }^{5}$.

Besides the residents of Vranovci, also as a consequence of the implementation of the "Free Emigration Agreement" between the FNR Yugoslavia and the Republic of Turkey, a large number of the population in Ovče Pole region, more precisely from the settlements of Dorfulia, Karatmanovo, Milino, etc., left their homes en masse and went to Turkey, and thus the life of the Bektashi tariqa in these places ended.

The only Bektashi family in the village of Dorfulia who opposed the mass migration to Turkey and remained to live in their birthplace is the Šerifov family. The oldest member of this family, Ajet Šerifov, together with his wife, brother and sister-in-law, were introduced to the Bektashi tariqa by the famous murshid of this area at that time, Halife-Baba Qazim Bakali, in 1962. While, his father Karaman as a muhib or full member of the Bektashi tariqa was appointed by Amza-Baba

From Đakovica ... Qazim-baba... From here, I became a member by him, by Qazim-Baba, 1962... Me, my brother ... and my wife, and they died, and so did yenge (sister-in-law) ... no tekke, at home... with ritual "muhabbet" ... We call the dervishes who, from the Bektashis, at dinner, we sacrifice an animal (kurban), that's all, rites and then we were like that. It is not just to enter. There is discipline here. The Bektashis have very strong discipline ... My father took it from Amza-Baba ${ }^{6}$.

There were only Turks in our village. There were a dozen, dervishes... there was no elder (baba). He went, there was, but he went to Turkey?

The last Bektashi elder who existed in Dorfulia was Veli-Baba. He and his family emigrated to Turkey in the 1950s.

Veli-Baba... He is here, until 57th, or 58th... he was not a baba, he will later become a baba... but there was no baba here, he did not come here ${ }^{8}$.

Such an expansion of emigration to Turkey will negatively affect the number of Turkish population in the village, and even more this emigration process will be devastating for the Bektashis and the Bektashi life in Dorfulia and the surrounding villages.

There were sixty before... began from 1953 to 1960. There were more than seventy families here, Bektashi... See, our family remained Šerifovi,

5 Own field research. Interlocutor Muharem Aksu (Osmanoski), born in 1945 in Gorno Vranovci. Today he lives in Izmir, Republic of Turkey.

6 Own field research, 2018, Durfulia. Interlocutor Ajet Sherifov, muhib in the Bektashi tariqat at the age of 76 , Turk.

7 Own field research, 2018, Durfulia. Interlocutor Ajet Sherifov, muhib in the Bektashi tariqat at the age of 76 , Turk.

8 Own field research, 2018, Durfulia. Interlocutor Ajet Sherifov, muhib in the Bektashi tariqat at the age of 76 , Turk. 
remained Müslüm-aga remained Niyazi-begova... Only three families left ... Today we are the only ones, my wife and I, there is no other here ${ }^{9}$.

Those who moved to Turkey will continue the Bektashi path in the new environment. In time, some of them will mature spiritually to the level of baba.

There are three babas from our village in Turkey, Izmir, from our village ... they come .. Feta-Baba, Sad'k-Baba, the third died Ali Ibrahim-Baba ${ }^{10}$.

Regarding the other villages in the vicinity of Dorfulia, my interlocutors reminded me that in the past Bektashis could be found in the villages: Tatarli (Milino) where the tomb of Ilmi-Baba is located, and in Karatmanovo where there is the tomb of Kamber-Baba.

Those bektashis who escaped this "free emigration" and who managed to stay in Macedonia and preserve the Bektashi shrines, some of them faced the communist government, its view on the religious issue, but also certain political decisions that directly affected the functioning of certain tekkes.

"The Communist Party in terms of the so-called religious issue at least declaratively proclaimed that the theistic or atheistic view of the world is a private right or personal freedom of every individual. In August 1945, the Council of Ministers of the Democratic Federal Yugoslavia issued a decree for establishing a state commission for religious affairs. (Илиевски, 2011: 35).“ „Within the republic governments, were formed republic commissions for religious affairs, which were to work according to the instructions of the state commission. The Religious Commission in Macedonia was established in 1945 and worked under the chairmanship of Epaminonda Pop Andonov. The task of this commission was to study the religious situation and to maintain contacts with the Orthodox Church as well as with the Muslim and Jewish religious community in Macedonia. (Илиевски 2011: 35)“.

From my interlocutors regarding religious freedom during socialism, I could hear more reserved statements. Most of them said that the Bektashis did not have any special problems and pressures from the that time government, but it was not all the same if a certain person, especially if a member of the party or employed in state bodies was seen going to worship or had a prominent role or title in religious organization, in this case in the Bektashi tariqa.

Listen, in Tito's time?... No, he did not create problems... No, no, he did not make any pressure... as it is now and then it was the same... For a time no one has interrupted. Nobody, nobody, nobody, the government has not stopped $^{11}$.

The services are nothing, so to speak, no, no. As in illegality, I can say they worked, the tekke worked. However, they did not cause any problems to

9 Own field research, 2018, Durfulia. Interlocutor Ajet Sherifov, muhib in the Bektashi tariqat at the age of 76 , Turk.

10 Own field research, 2018, Durfulia. Interlocutor Ajet Sherifov, muhib in the Bektashi tariqat at the age of 76 , Turk.

11 Own field research, 2017, southern part of Macedonia, muhib in the Bektashi tariqat at the age of 70 , a Turk. 
anyone and went to worship, returning to prayers. They came back, people gathered and they left. So this work, the Bektashi path went from hand to hand, from generation to generation. It is not extinguished at all in Macedonia ${ }^{12}$.

Despite this picture of the moderate attitude of the communist government towards the Bektashis and their sanctuaries, in this period a political decision appears, i.e. a law on nationalization was adopted which will have a negative effect on certain tekkes. One of the Bektashi tekkes that was a victim of this decision, where the local authorities decided to usurp it and turn it into a tourist facility is the Harabati-Baba tekke in Tetovo. Certain parts of this tekke were converted into a hotel, restaurant, and disco in the 1970s, denying Bektashi believers the right to freely profess their faith and access their centuries-old sanctuary. During this period, due to the drunken depravity of numerous guests in the hotel, restaurant and disco, led to the desecration of the tombstones, during which they were destroyed and urinated, and also the main complex with the türbes was burned, causing significant damage to the graves of many saints buried in them. For some time, the museum of the Tetovo area was located within the tekke. Spiritual services during these breaks were performed by Bektashis in houses or in Bektashi tekkes in other cities.

But, in Tetovo yes. It was extinguished in Tetovo. Do you know why? Because with the law on nationalization, we know that in the year 1945, then it was, communism came in, that is, the new Socialist Republic of Yugoslavia, the Federal Republic of Yugoslavia, was constituted and then nationalization took place in a short time. The law on nationalization was adopted. It was immediately, 1956-57. By law, all religious buildings throughout Yugoslavia were confiscated. Both to the Christian world and to the Muslim world... The tekke was later confiscated and after that, after a few years, it was given to the municipality of Tetovo. The municipality did not keep it for a long time, for two or three years they kept it, and immediately handed it over to the Teteks company, there was one big company Teteks. And Teteks later restored the building, made it a museum, brought it into a museum condition. When you want to go to the türbes, you could go with a ticket, they turn it into a museum... That's how it was. There was not then. There was no erkan there. We who call ourselves Bektashis did not follow the path of Bektashis there. There wasn't any ${ }^{13}$.

The tekke did not work, we know from 1946 to 1994 did not work... During communism did not work. On the twentieth of march 1994 we entered here with Baba Tayar, we enter. We enter for three days. Tayar Gashi. We enter for three days to celebrate Sultan Nevruz in that room, in these rooms. We got permission, that time Gjuner Ismail was the Minister of Culture. Ten days

12 Own field research, 2019, western part of Macedonia, baba in the Bektashi tariqat at the age of 59 , a Turk.

13 Own field research, 2019, western part of Macedonia, grandmother in the Bektashi tariqat at the age of 60 , a Turk. 
without eating, without drinking this-that. And we remained and it continued in ninety four ${ }^{14}$.

One of the few Bektashi tekkes that managed to escape the clutches of the communist government and prolong its life was the Hussein-Baba tekke in Bitola. According to the "Five-Year Plan" (Закон за Петгодишниот план, 1947) for the development of the city of Bitola, this building should have been completely demolished. But, thanks to Hussein Taipi, a prominent resident of the village of Asamati, Prespa, at the same time muhib, a full member of the Bektashi tariqa, but above all a partisan and sympathizer of the Communist Party (a really interesting combination), who managed to persuade the local authorities to exclude this teke of the five-year plan and allow the Bektashis to continue to perform their religious rites in this precious sanctuary.

After 1949, it was suspicious to the government ... they wanted to demolish the tekke. The plan... the five-year plan, the first five-year plan included the tekke... and now it should be demolished... And there was a tomb of Usein-Baba and Suleyman-Baba, there, in the türbe, in a house, everything is like that... My father was, how should I say, muhib in the tekke... My father was also a member of the party. And my father, because he was a muhib, during the fight, my father was a supporter, he collaborated with Jovko Jovkoski from Ljubojno; Jovko Jovkoski was the leader for all of Prespa, illegal... Because then in Prespa, in the partisan army, in the partisanship only our family entered from the Albanians... Only my brother and my father took an active part... And when that happened, the Sali-Baba went and asked my dad: "-see Usain, please do not tear down the tekke. Please pray here, for the old people to go. For the old, let the youth go their own way... And my father went to Bitola and met Vasko Karangeleski, Dane Petkoski they were generals... And with those leaders in Bitola, my brother was a partisan with them... with the fighters he met there... in the village of Kurbinovo at the church, he met there. He was transmitting mail from Albania here, I was reading the mail... And went to these fighters that I told you in Bitola and told them this and this and this... Yes that's right. He said, do not tear down the tekke. „- Let it, there are old people, let them pray. Old people, He is our Lord. Such as believers. And they said: "No, it will be demolished... we will demolish it!! And so he said to them: "-Okay," he said. "Come on, destroy the churches"! He said to them, "Destroy the churches, destroy the tekke." And then, they stopped ${ }^{15}$.

In this way, Hussein-Baba Teke in Bitola survives this threat of destruction, and the most deserving for that, as I mentioned, are Taip Taipi and his father Hussein Taipi from Asamati.

After this event, whether frightened by the communist government, the tekke began to take on a more closed form. Not that it was completely closed to

14 Own field research, 2018, western part of Macedonia, dervish in the Bektashi tariqat at the age of 68 , Albanian.

15 Own field research, 2017, northern part of Macedonia, muhib in the Bektashi tariqat at the age of 89 , Albanian. 
the faithful, but, in a way, the rituals and even the visits were reduced and took place in secret.

Today, the Hussein-Baba tekke in Bitola does not function conditionally. I say conditional because certain information that I came across say that Bektashi life is still present in it, but it is kept in the greatest secrecy. The reasons for this situation are known only to the head of this tekke, and his closest surrounding. And the rest of us can only guess about this cover-up, whether it is for political, religious, ethnic or any other reason.

Regarding the sanctuary H'd'r-Baba in Makedonski Brod, which many Bektashi believers consider to be one of the oldest Bektashi temples on the territory of Macedonia, some interesting information in the socialist period, we find in Elizabeta Koneska which are based on her field research done in Makedonski Brod and Kičevo. They say that after World War II the shrine was rather neglected and gradually ruined, although it was still visited, especially by the Muslim Bektashis. One of interlocutors informed her that the Bektashis from Kanatlarci, after a short visit to the türbe/tekke, where there were no conditions for prayers, often received them in his house, not far from the türbe, where they performed their rituals in the largest room on the second floor with prayers and singing spiritual songs (Конеска, 2006: 165).

„In the late 70 or or early 80 os of the 2oth century, an initiative was probably launched for the protection and restoration of the tekke, i.e. the türbe. The competent metropolitan responded to the alleged initiative with an action for renovation of the building. A report was made on the condition of the churchturbe of St. Nicholas during 1984, which states, among other things, that the church was unlocked by the servant Hristina Terzioska, and inside the holy throne and icons there were many "elements of the Islamic religion." The floor was partially covered with sheep and lamb skins, and an "improvised Turkish tomb" was placed in the middle, on which the believers had left rich gifts. The minutes state that the believers respected it as the tomb of St. Nikola, i.e. AjdarBaba. Then the wooden coffin of the tomb had a roller shape, made of green colored planks, which was placed in the center and was moved one meter towards the south wall (Записник б.б. составен на ден 8.4.1984 cited in: Конеска 2006: 165). At the end of the 80's, the building was renovated, with an iconostasis, and during 1994 the building was consecrated as a church (Конеска, 2006: 166).“

As for the Bektashi community in Struga, unfortunately we can conclude that it does not exist today. There may be some individuals who are difficult to reach, due to the closed nature of the group / family that secretly follows the Bektashi path. Unlike in the socialist period, around the 5os of the twentieth century, Struga was a fertile environment for the spiritual development of the Bektashis, managed by the widely known and respected Kalender Usni QemalBaba. In the absence of a Bektashi tekke in Struga, most of the religious rites were held in the house of Usni Qemal-Baba where he had adapted a square for the needs of the tariqa.

Exactly about Usni Qemal-Baba, I received first-hand information from my interlocutor Didar Doko, who is the granddaughter of the sister of the respected 
baba Kalender Usni Qemal Seyran: My uncle, Usni Qemal-Baba, he is my born uncle. My mother's brother. He was Kalender, mujaret (virgin), with QazimBaba serving at the same time. My uncle died in 1963 with the earthquake... he was my uncle. The most important in Macedonia, perhaps in the Balkans. It is a kalendar, they watched it at the same time in Skopje, in Tetovo, in Štip in Ohrid in Kanatlarci, everywhere at the same time at twelve o'clock...

Besides her uncle Usni Qemal-Baba, my interlocutor came up with two other Bektashis at that time in Struga, Ajdar and Ali Vishto: Ajdar Adzo was a Bektashi in Struga, across the Drim Hotel, and Ali Vishko. His mother, from Ali Vishko and my mother are from two sisters. They originated from Albania. They are also Bektashis ${ }^{16}$.

As for the existence of Bektashi tekkes in Struga, Didar will say: in Struga they did not have Bektashi tekkes, de facto and de jure, no, no ${ }^{17}$.

Milenko Filipovic researching in the 50s of the 20th century in the Strumica region gives certain data on the existence of Bektashis in the villages: Banjsko, Svidovica and Makrijevo (Mokrievo) in the area of Podgorje or Podgorija, under the northern slopes of Belasica. He says that the village of Svidovica is their center, where the Turks are exclusively Bektashi, unlike in Makrijevo and Banjsko, where they are mixed, there are Bektashi and Melamic supporters. Filipović adds that Bektashis are also found in the village of Zleovo (Radoviš region). For all places in this region where Bektashis are found, the main Bektashi tekke is located in Štip (Filipović, 1954: 10-13).

One important fact that I think should be shared, related to the tariqa life in Yugoslavia, is the establishment of an independent organization Alliance of the Islamic Dervish Order of Aliya" (SIDRA) in 1974, based in Prizren, as an umbrella organization aimed at advancing the study and practice of tasawwuf. This organization started publishing its own magazine entitled "HU". Four years later, the organization changed its name to ZIDRA - Community of the Islamic dervish orders of Alia in SFRY. According to HU magazine, in 1978 the number of dervishes in Yugoslavia exceeded fifty thousand. (Čolić, 1995: 9).

ZIDRA is being formed... All tariqas belong to this community who express a wish to be part of this association. Here is shey(h) Đemal, I know him. I saw him, he was the first president of that, of that association... Sheikh Đemal. Sheikh Đemal Shehu. That is his last name... At the level of Yugoslavia. It's like meshehat, meshehat. Association of the tariqas of the sheikhs... Now, in the eighties, from 1978, it can be formed. From the 1978, I think so, I remember so. 1978 I think it is ${ }^{18}$.

16 Own field research, 2019, western part of Macedonia. Muhib in the Bektashi tariqat at the age of 67.

17 Own field research, 2019, western part of Macedonia. Muhib in the Bektashi tariqat at the age of 67.

18 Own field research in Ohrid, 2018. Interlocutor Eyup Salih, born on September 22, 1950 in Ohrid, Muslim, Turk. 
This organization SIDRA or (later) ZIDRA with its action will really contribute to the revival but at the same time preservation of the tariqa life in Yugoslavia, especially in the last decade of the socialist period.

\section{Conclusion}

Through this paper I hope that I managed to transfer the readers in time to the socialist period in the Republic of Macedonia, but also to introduce them to the circumstances under which the Bektashi dervish order existed.

From the appearance of the Bektashi tariqa in Macedonia until today, there is a continuity in its existence, surely in certain oscillations in different periods. As for the Bektashi tariqa in Macedonia during socialism, certain occurrence, opportunities and processes will be the main instigator for its further course.

An important occasion is the "Free Emigration Agreement", concluded between the Federal Republic of Yugoslavia and the Republic of Turkey in the 1950s, which was dire to the tariqa life and tekkes in Macedonia, due to the mass exodus of the Muslim population to Turkey. Many Bektashi tekkes in the area of Macedonia are devastated as a result of the displacement of the population.

Those Bektashis who escaped this "free emigration" and who managed to stay in Macedonia and preserve the Bektashi shrines, some of them faced the communist government, its view on the religious issue, but also certain political decisions that directly influenced the functioning of certain tekkes.

In this period, a political decision appears, i.e. a law on nationalization adopted, which will have a negative effect on certain tekkes. One of the Bektashi tekkes that was a victim of this decision, where the local authorities decide to usurp it and turn it into a tourist facility is the Harabati-Baba tekke in Tetovo.

In addition to the law on nationalization, another political decision in this period that will affect Bektashi life is the adoption of a law on the Five-Year Development Plan which will be fatal for certain Bektashi shrines.

On the other hand, it can be said that the government in Macedonia in the socialist period was more tolerant of the religious issue, compared to other neighboring countries, where at least declaratively proclaimed that the theistic or atheistic view of the world is a private right or personal freedom of everyone. individual. In certain Bektashi tekkes in Macedonia, without any serious obstructions, the Bektashi tariqa life continued during socialism.

Unlike in neighboring Albania, with the communist takeover in 1945, Bektashi influence would gradually diminish, most recently in 1967, when Enver Hoxha banned all religious practices. In Albania, the Bektashi tariqa will be completely paralyzed.

A similar fate befell the Bektashi tariqa in Bosnia and Herzegovina when in 1952 tariqa activities, including the Bektashi tariqa, were completely banned, but not from the communist government, as one might think at first glance, but from the modernist ulema who ruled the Islamic community (strongly influenced 
by the governing structures) and regarded the dervish orders and sheikhs as backward archaic superstition and innovation (bidah) in faith.

This ban lasted until the 7os of the last century, when, thankfully to the efforts of the famous scholars of the Muslim community Qadiri-Mevlevi sheykh and imam Fejzulah Hadžibajrić (d. 1990) and the Rifai sheykh from Prizren Đemali Shehu, there is a resurgence of sufism in Yugoslavia. In 1974, the "Alliance of the Islamic Dervish Order of Aliya" (SIDRA), based in Prizren, was established as an independent organization, as an umbrella organization to promote the study and practice of tasawwuf. This organization SIDRA or (later) ZIDRA with its activities will really contribute to the revival but at the same time to the preservation of the tariqa life in Yugoslavia, especially in the last decade of the socialist period.

\section{Sources}

ДАРМ, ф. Претседателство на Влада на НРМ, 159. 2. 53/241 - 247, Извештај за работата и организацијата на Верската комисија, 5. VII. 1945 година, in: Илиевски, Борче. 2011. Макеgонско-сриескииее црковни оgноси 1944-1970, Скопје: Институт за историја, Филозофски факултет.

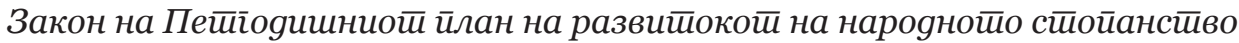

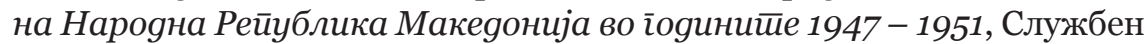
весник на Народна Република Македонија, бр. 24, год. III, Скопје, 1947.

Службен весник на ДФЈ, I/62, 21 август 1945 година, Уредба за основање Државна комисија за верски прашања, in: Илиевски, Борче. 2011. Макеgонско-сриескийе црковни оgноси 1944-1970. Скопје: Институт за историја, Филозофски факултет.

Службен весник на Р Македонија бр. 113, 20.9.2007.

Novaković, Konstantin, Foto esej: Derviško proleće u Prizrenu, http://pescanik. net/foto-esej-dervisko-prolece-u-prizrenu/, accessed on: 10.11.2019.

Tapu defteri No. 232, s 210a, Istanbul, Başbakanlık Arsivi, in: Петровски, Трајан. 1994. Дервишки ирсиеен. Скопје: Култура.

The Path to Insight, http://bektashiorder.com/the-path-to-insight, accessed on: 9.3.2015. 


\section{References}

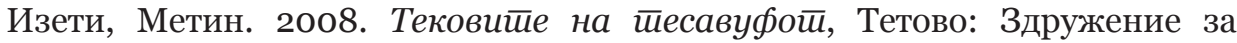
културна афирмација „СКОФИА“.

Илиевски, Борче. 2011. Макеgонско - срӣскийе црковни оgноси 1944-1970, Скопје: Институт за историја, Филозофски факултет.

Јордановска, Станислава. 2014. Празникой Ашуре кај gервишкиой реg

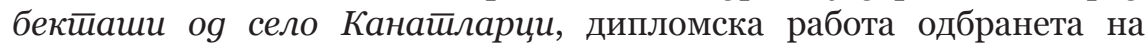
Институтот за етнологија и антропологија, Природно-математички факултет, supervisor: Љупчо Ристески, PhD on IEA, FNM, UKIM in Skopje, manuscript.

Конеска, Елизабета. 2006. „Дилеми околу историјата на црквата Св. Никола или Х’д’р баба турбето во Македонски Брод“, Гласник 50 (1): 161 - 168.

Конеска, Елизабета. 2008. „Денот на ашуре кај тарикатите во Македонија“,

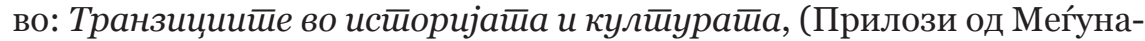
родната научна конференција одржана во Скопје на 30-31 октомври 2006 година, во соработка со Етнографскиот институт со музеј при Бугарската академија на науките), 421 -430. Скопје: Институт за национална историја.

Конеска, Елизабета. 2009. „Преглед на бекташкиот дервишки ред во Р.

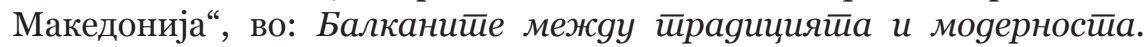

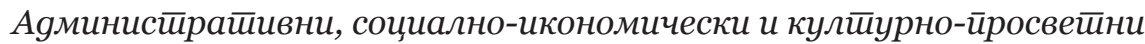

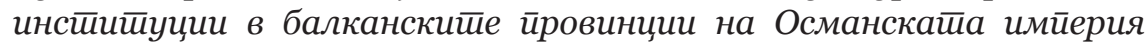
(ХVIII-XIX век), 229 -255. София: ИК „ГУТЕНБЕРГ“.

Петровски, Трајан. 1994. Дервишки ӣрсиеен, Скопје: Култура.

Светиева Анета. 2000. „Социјална култура на четири Велешки села: Теово, Ореше, Мелница и Горно Врановци“, во проект The Multicultural and Ethnic Characteristics of Four Villages in the Veles Region - Republic of Macedonia, on: http://www.ethnologs-dep.org/VELES/indexV.htm, accessed on: 04.05.2014 r. Web page is not active. 
Стојановски, Александар. 1979. „Едно потврдено предание“, Музејски іласник на Исииорискиой музеј на Макеgонија 4: 53 - 57. Скопје.

Стојановски, Александар (редактор). 1998. „Македонија под турска власт (од XIV до крајот на XVIII век)“, во: Исйорија на макеgонскиой нароg, том втори. Скопје: Институт за национална историја.

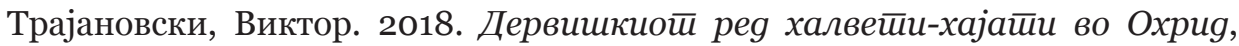
Скопје: Институт за етнологија и антропологија, Центар за етнолошки истражувања и применета антропологија.

Што е тоа Суфизам, on: http://www.islamska-zaednica.com/forum/topic/945што-е-тоа-суфизам/, пристапено на: 12.12.2016.

Abiva, Hüseyin. A Glimpse at Sufism in the Balkans, https://www.alevibektasi.eu/index.php?option $=$ com content $\& v i e w=$ article $\&$ id $=689 \% 3 \mathrm{Aa}-$ glimpse-at-sufism-in-the-balkans \&catid $=46 \% 3$ Aaratrmalaringilizce\&Itemid=69, пристапено на: 28.8.2018.

Birge, John Kingsley. 1937. The Bektashi Order of Dervishes, Luzac \& CO., London W.C.

Ćehajić, Džemal. 1986. Derviški redovi u jugoslovenskim zemljama sa posebnim osvrtom na Bosnu i Hercegovinu, Sarajevo: Grafo-art atelje.

Čolić, Ljiljana. 1995. Derviški redovi muslimanski: Tekije u Skoplju, knjiga LXXIV. Beograd: Filološki fakultet u Beogradu.

Filipović, Milenko S. 1954. „The Bektashi in the District of Strumica (Macedonia)“, Man 54: 10-13.

Hasluck, Frederick William. 1929. Christianity and Islam under the Sultans, Vol. II. Oxford: Clarendon Press.

Izeti, Metin. 2001. Tarikath Bektashian, Tetovë:„,̧̧abej“.

Kara, Mustafa, Din Hayat Sanat Açısından Tekkeler ve Zaviyeler, Istanbul 1999, цитирано во: Изети, Метин. 2008. Тековиие на ииесавуфой, Тетово: Здружение за културна афирмација „СКОФИА“. 
EthnoAnthropoZoom 
EthnoAnthropoZoom 